\title{
KARAKTERISTIK DAN PENGOBATAN PASIEN GASTRITIS DI PUSKESMAS WONOREJO SAMARINDA
}

\author{
Puji Rahayu ${ }^{1}$, Welinda Dyah Ayu, Laode Rijai \\ Laboratorium Penelitian dan Pengembangan FARMAKA TROPIS \\ Fakultas Farmasi Universitas Mulawarman, Samarinda, Kalimantan Timur \\ *email: pujirahayueljuan@gmail.com
}

\begin{abstract}
ABSTRAK
Gastritis merupakan salah satu masalah kesehatan saluran pencernaan yang paling sering terjadi. Dari data Dinas Kesehatan Kota Samarinda tahun 2013, gastritis masuk dalam daftar 10 penyakit terbanyak dengan urutan ke-2. Namun sampai saat ini, gastritis masih dianggap sebagai suatu hal yang remeh atau biasa. Penelitian ini bertujuan untuk mengetahui karakteristik dan pengobatan pasien gastritis di Puskesmas Wonorejo Samarinda. Jenis penelitian ini bersifat prospektif. Teknik pengambilan sampel dengan cara purposive sampling. Populasi penelitian ini adalah pasien yang berobat di Puskesmas Wonorejo dengan banyak sampel 41 pasien. Hasil penelitian menunjukkan bahwa pasien gastritis di dominasi oleh wanita $65,85 \%$, pada kelompok usia $36-45$ tahun $36,60 \%$, pendidikan terakhir adalah SMA 58,54\%, pekerjaan Swasta 31,70\%, merokok 50\%, mengonsumsi obat NSAID 53,66\% dan pola makan cukup 56,10\%. Pengobatan pasien gastritis di bedakan menjadi 3 golongan, yaitu Antasida 21,95\%, H2 reseptor antagonis menggunakan Famotidin 12,19\% dan Ranitidin 53,67\% serta Pompa Proton Inhibitor menggunakan Omeprazol 12,19\%.
\end{abstract}

Kata kunci: Gastritis, Karakteristik pasien, Pengobatan

\section{ABSTRACT}

Gastritis is one of medical problem on gastrointestinal system most often occur. Statistic from Samarinda City Health Department in 2013, gastritis included in the list of 10 diseases with No-2. But, till nowadays, gastritis still considered as a trifle problem. This research is conducted to find out the characteristic and treatment on gastritis patient in Community Health Center of Wonorejo Samarinda. This research is prospective research. The technique in taking sample of this research is using purposive sampling. The population of this research are patients of Community Health Center of Wonorejo with amount of sample are 41 patients. The result of this research shows that the patients gastritis dominated by female $65,85 \%$, on the age of 36-45 years old 36,60\%, last education of high school 58,54\%, an Private employee 31,70\%, smoker 50\%, NSAID consumer 53,66\% and enough eating behavior 56,10\%. Treatment on gastritis patient are differentiate into 3 kinds, they are antacid 21,95\%, $\mathrm{H} 2$ receptor antagonist use famotidine 12,19\% and ranitidine 53,67\%, and Pompa Proton Inhibitor use omeprazole 12,19\%.

Keywords : Gastritis, patient characteristics, treatment 


\section{PENDAHULUAN}

Penggunaan obat yang tepat merupakan langkah penting untuk mendapatkan kesehatan yang lebih baik terhadap pasien itu sendiri sehingga sembuh dan sehat yang diinginkan menjadi terwujud. obat secara baik. Akibatnya obat yang digunakan tidak dapat meringankan atau menyembuhkan penyakit bahkan dapat terjadinya resistensi serta dapat membahayakan terhadap penyalahgunaan antibiotik.

Gastritis merupakan salah satu masalah kesehatan saluran pencernaan yang paling sering terjadi. Badan penelitian WHO (World Health Organization) mengadakan tinjauan terhadap beberapa negara di dunia dan mendapatkan hasil persentase dari angka kejadian gastritis di dunia, diantaranya Inggris 22\%, China 31\%, Jepang 14,5\%, Kanada 35\% dan Perancis $29,5 \%$. Menurut WHO di Indonesia angka kejadian gastritis beberapa daerah juga cukup tinggi dengan prevalensi 274.396 kasus dari 238.452.952 jiwa penduduk. Menurut Maulidiyah (2006), di kota Surabaya angka kejadian gastritis sebesar 31,2\%, Denpasar 46\% dan kejadian gastritis yang tertinggi terdapat di kota Medan yaitu sebesar 91,6\%.

Dari data Dinas Kesehatan Kota Samarinda tahun 2013, gastritis masuk dalam daftar 10 penyakit terbanyak dengan urutan ke 2 . Namun sampai saat ini, gastritis masih dianggap sebagai suatu hal yang remeh atau biasa. Padahal gastritis merupakan awal dari penyakit yang dapat menganggu aktivitas, selain itu juga dapat menyebabkan kanker lambung bila tidak ditangani dengan baik serta dapat berakibat fatal hingga mengakibatkan kematian. Secara garis besar beberapa faktor pemicu timbulnya gastritis dikelompokkan dalam empat golongan, antara lain faktor makanan, obat-obatan dan zat kimia, faktor psikologi serta infeksi bakteri. Selain itu juga penggunaan obat dan dosis yang kurang tepat sehingga tidak memberikan efek atau dapat membahayakan bagi pasien gastritis.

Berdasarkan hal tersebut, maka peneliti ingin mengetahui karakteristik dan pengobatan pasien gastritis untuk meningkatkan pengobatan yang lebih baik Namun, hingga saat ini masih banyak masyarakat yang tidak mengikuti aturan penggunaan obat yang tepat, bukan hanya terhadap penyakit yang berat saja tetapi pada penyakit yang dianggap ringan pun seperti gastritis, masyarakat belum juga menggunakan

serta mendapatkan gambaran mengenai karakteristik pasien gastritis berdasarkan umur, jenis kelamin, pekerjaan, pendidikan, kebiasaan merokok, pola makan dan konsumsi obat NSAID.

\section{METODE PENELITIAN}

Penelitian ini merupakan penelitian deskriptif secara prospektif dengan memberikan lembar data pasien gastritis di Puskesmas Wonorejo Samarinda periode Agustus 2016 September 2016. Jumlah sampel yang di peroleh sebanyak 41 pasien dengan metode purposive sampling.

Populasi pada penelitian ini adalah pasien gastritis di Puskesmas Wonorejo Samarinda periode Agustus 2016 - September 2016. Kriteria inklusi sampel penelitian yaitu pasien yang berobat di puskesmas Wonorejo Samarinda, pasien yang menderita gastritis dan bersedia untuk menjadi responden, dapat berbahasa Indonesia serta dapat membaca. Sedangkan kriteria ekslusi sampel penelitian yaitu pasien yang memiliki penyakit peserta berat, pasien dengan usia di bawah 15 tahun.

Data yang digunakan merupakan data primer yang diperoleh dari pengisian lembar data pasien dan data sekunder yang diperoleh dari pencatatan dan pelaporan mengenai gastritis di puskesmas Wonorejo Samarinda. Data yang diperoleh kemudian diolah menjadi bentuk persentase dan disajikan dalam bentuk tabel atau diagram. 
HASIL DAN PEMBAHASAN

\section{Karakteristik Pasien}

\section{a. Berdasarkan Jenis Kelamin}

Tabel 1. Distribusi berdasarkan jenis kelamin pasien gastritis di Puskesmas Wonorejo Samarinda Periode Agustus 2016 - September 2016

\begin{tabular}{lcc}
\hline \multirow{2}{*}{ Jenis } & \multicolumn{2}{c}{ Jumlah } \\
\cline { 2 - 3 } Kelamin & Frekuensi & Persentase (\%) \\
\hline Perempuan & 27 & 65,85 \\
Laki-laki & 14 & 34,15 \\
\hline Total & $\mathbf{4 1}$ & $\mathbf{1 0 0}$ \\
\hline
\end{tabular}

Berdasarkan hasil penelitian diketahui bahwa pasien gastritis di Puskesmas Wonorejo Samarinda Periode Agustus 2016 - September 2016 lebih banyak terjadi pada kelompok perempuan yaitu sebanyak 27 pasien $(65,85 \%)$ dibandingkan dengan kelompok laki-laki yaitu sebanyak 14 pasien $(34,15 \%)$.

Hal ini dimungkinkan karena perempuan biasanya merasa takut gemuk sehingga sering diet berkepanjangan yang menyebabkan makan tidak teratur, selain itu juga perempuan lebih mudah stres dibandingkan dengan laki-laki yang disebabkan oleh mekanisme hormonal. Menurut Sunaryo (2004), perempuan sangat mudah mengalami stres ketika terjadi perubahan sistem hormonal. Proses fisiologis di dalam tubuh terjadi ketika reseptor menerima rangsangan dari stresor untuk pertama kalinya. Rangsangan tersebut diteruskan menuju hipotalamus yang menyebabkan hipotalamus mengeluarkan hormon corticotrophin-releasing factor (CRF) yang menstimulasi kelenjar anterior pituitari untuk mengeluarkan adenocorticotrophic hormone (ACTH) yang kemudian menstimulasi kelenjar adrenal untuk mengeluarkan hormon kortisol (hydrocortisone), adrenalin (adrenaline) dan noradrenalin (norephinephrine). Pengeluaran hormon kortison akibat stres ini dapat mengurangi daya tolak lambung terhadap asam lambung sehingga menyebabkan terjadinya masalah pencernaan (Choiro, 2014). Hasil penelitian ini sesuai dengan hasil penelitian yang dilakukan oleh Rahma dkk (2012) yang melaporkan bahwa perempuan lebih besar beresiko terkena gastritis dan lebih banyak menderita gastritis daripada laki-laki. Hal ini disebabkan karena perempuan lebih memperhatikan citra tubuhnya sehingga banyak dari mereka yang menunda makan, mengurangi porsi makan sesuai kebutuhannya bahkan puasa panjang agar memiliki porsi tubuh yang ideal, juga remaja dan usia masa dewasa awal dengan masa dewasa akhir tidak berbeda jauh. Dan masih dikatakan dalam kategori usia produktif. Pada usia tersebut merupakan usia dengan berbagai kesibukan yang dilakukan karena pendidikan, pekerjaan, keluarga dan kegiatan lainnya. Sehingga lebih cenderung untuk terkena faktorfaktor lain yangdapat meningkatkan resiko untuk terkena gastritis, seperti halnya stres dengan pendidikan, pekerjaan, keluarga ataupun masalah lain serta pola hidup tidak sehat akibat berbagai aktivitas dan kesibukan yang dilakukan pada usia produktif tersebut.sering mengkonsumsi makanan dan minuman iritatif serta rentan stres. Begitupun menurut Hanik (2010), dikatakan ada hubungan antara jenis kelamin dengan kejadian gastritis bahwa responden dengan jenis kelamin perempuan memiliki resiko 3,059 kali untuk terkena gastritis dibandingkan dengan responden berjenis kelamin laki-laki. 


\section{b. Berdasarkan Usia}

Tabel 2.Distribusi berdasarkan usia pasien gastritis di Puskesmas Wonorejo Samarinda Periode Agustus 2016 - September 2016

\begin{tabular}{lcc}
\hline \multicolumn{1}{c}{ Usia } & \multicolumn{2}{c}{ Jumlah } \\
& Frekuensi & Persentase (\%) \\
\hline 16-25 tahun & 13 & 31,70 \\
26-35 tahun & 13 & 31,70 \\
36-45 tahun & 15 & 36,60 \\
\hline Total & $\mathbf{4 1}$ & $\mathbf{1 0 0}$ \\
\hline
\end{tabular}

Berdasarkan hasil penelitian diketahui bahwa pasien gastritis di Puskesmas Wonorejo Samarinda Periode Agustus 2016 - September 2016 lebih banyak terjadi pada usia 35-45 tahun (masa dewasa akhir) yaitu sebanyak 15 pasien $(36,60 \%)$, dibandingkan usia 1625 tahun (remaja akhir) dan usia 26-35 tahun (dewasa awal) yaitu sebanyak 13 pasien $(31,70 \%)$.

Hal ini dimungkinkan karena dengan bertambahnya usia maka organ pun akan mengalami penurunan daya kerja hingga semakin lemah begitupun dengan mukosa lambung. Hasil penelitian ini sesuai dengan Yanti (2010), bahwa semakin bertambahnya usia maka semakin mudah terkena penyakit gastritis. Hal ini menunjukkan bahwa seiring dengan bertambahnya usia mukosa gaster cenderung menjadi tipis sehingga lebih cenderung memiliki infeksi Helicobacter pylori atau gangguan autoimun daripada orang yang lebih muda. Menurut Badan Pusat Statistik Indonesia (2013), komposisi penduduk Indonesia menurut kelompok umur terdiri dari penduduk berusia muda (0-14 tahun), usia produktif (15-64 tahun) dan usia tua ( $\geq 65$ tahun). Berdasarkan Tabel 2, dapat dilihat bahwa perbandingan antara usia masa penelitian ini tidak sesuai dengan Yanti (2010), dimana tingkat pendidikan mempengaruhi tingkat pengetahuannya terhadap gastritis. Begitupun dengan hasil penelitian Zilmawati (2007) yang menunjukkan bahwa ada hubungan yang bermakna antara tingkat pengetahuan dengan kejadian gastritis. Semakin tinggi tingkat pendidikan yang dimiliki, maka semakin tinggi pula pengetahuan dan perilaku pencegahan terhadap kejadian gastritis. Namun, hasil penelitian ini sesuai dengan penelitian yang dilakukan Rahmi (2011), bahwa tidak ada hubungan yang signifikan antara tingkat pendidikan dengan kejadian gastritis. Hal ini dimungkinkan belum tentu semua responden menerapkan atau mengaplikasikan semua informasi yang diketahuinya yang berkaitan dengan gastritis.

\section{c. Berdasarkan Tingkat Pendidikan}

Tabel 3.Distribusi berdasarkan tingkat pendidikan pasien gastritis di Puskesmas Wonorejo Samarinda Periode Agustus 2016 - September 2016

\begin{tabular}{lcc}
\hline \multicolumn{1}{c}{ Tingkat } & \multicolumn{2}{c}{ Jumlah } \\
Pendidikan & Frekuensi & Persentase (\%) \\
\hline SD & 6 & 14,63 \\
SMP & 7 & 17,07 \\
SMA & 24 & 58,54 \\
Sarjana & 4 & 9,76 \\
\hline Total & $\mathbf{4 1}$ & $\mathbf{1 0 0}$ \\
\hline
\end{tabular}


Berdasarkan hasil penelitian diketahui bahwa pasien gastritis di Puskesmas Wonorejo Samarinda Periode Agustus 2016 - September 2016 lebih banyak terjadi pada kelompok tingkat pendidikan SMA yaitu sebanyak 24 pasien $(58,54 \%)$ dibandingkan dengan kelompok SMP dengan jumlah 7 pasien $(17,07 \%)$, kelompok SD dengan jumlah 6 pasien $(14,63 \%)$ dan kelompok Sarjana dengan jumlah 4 pasien $(9,76 \%)$. Pada tingkat pendidikan SMA umumnya masyarakat memiliki pengetahuan dan kesadaran yang cukup terhadap pentingnya kesehatan sehingga memiliki keinginan untuk melakukan proses berobat demi tercapainya kesembuhan dan pencegahan berlanjutnya proses penyakit, pencegahan penyakit menular dan pencegahan komplikasi (Suhita, 2008). Hasil hingga menumpuk, jadwal kerja yang berkepanjangan hingga menyebabkan terbebaninya akan pekerjaan dan menimbulkan stres. Penelitian ini sesuai dengan hasil penelitian yang dilakukan oleh Prasetyo (2015), bahwa pekerjaan responden mayoritas sebagai swastan yakni buruh pabrik dimana sering mengalami stres tingkat menengah hingga tinggi terdapat pada $73,25 \%$ pekerja gilir (shift), dimana stres tersebut lebih banyak terjadi pada pekerja yang terpapar bising dibandingkan yang tidak terpapar. Menurut Nasution (2011), stres merupakan salah satu dari tujuh penyakit yang paling sering terjadi pada pekerjaan yang diemban. Stres tertinggi pada pekerja sebagai staf atau pegawai. Stres yang terkait dengan pekerjaan ini disebut sebagai stres okupasi, dimana stres yang terjadi karena respon fisik dan emosi yang muncul saat kebutuhan pekerjaan tidak sesuai dengan kapabilitas, daya atau kebutuhan pekerja sehingga terjadi tekanan yang berlebihan baik reaksi fisik dan psikologis. Pada usia produktif inilah dengan banyaknya tuntutan kerja membuat seseorang terkadang memiliki kebiasaan makan yang tidak teratur. Begitupun juga dengan pelajar/mahasiswa, dimana banyaknya tugas yang menumpuk, mudahnya stres karena pergaulan remaja saat ini dengan kisah asmara. IRT yang juga bekerja terhadap pengasuhan anak, keluarga dan lainnya begitupun dengan pekerjaan pedagang dan PNS.

\section{d. Berdasarkan Pekerjaan}

Tabel 4. Distribusi berdasarkan pekerjaan pasien gastritis di Puskesmas Wonorejo Samarinda Periode Agustus 2016 - September 2016

\begin{tabular}{lcc}
\hline Pekerjaan & \multicolumn{2}{c}{ Jumlah } \\
& Frekuensi & Persentase (\%) \\
\hline PNS & 3 & 7,32 \\
Pelajar/Mhs & 9 & 21,95 \\
IRT & 9 & 21,95 \\
Swasta & 13 & 31,70 \\
Pedagang & 7 & 17,07 \\
\hline Total & $\mathbf{4 1}$ & $\mathbf{1 0 0}$ \\
\hline
\end{tabular}

Berdasarkan hasil penelitian diketahui bahwa pasien gastritis di Puskesmas Wonorejo Samarinda Periode Agustus 2016 - September 2016 lebih banyak terjadi pada kelompok pekerjaan swasta yaitu sebanyak 13 pasien $(31,70 \%)$, dibandingkan dengan kelompok pelajar/mahasiswa dan IRT sebanyak 9 pasien (21,95\%), kelompok pedagang sebanyak 7 pasien $(17,07 \%)$ serta kelompok PNS sebanyak 3 pasien $(7,32 \%)$.

Hal ini dimungkinkan karena pekerjaan sebagai pegawai swasta yang bekerja di bawah naungan pribadi seperti halnya bekerja di sebuah perusahaan yang mana banyak aturan yang dilakukan, pekerjaan yang harus diselesaikan dalam tenggang waktu dekat gastritis di Puskesmas Wonorejo Samarinda Periode Agustus 2016 - September 2016 lebih banyak terjadi pada kelompok pola makan cukup yaitu sebanyak 22 pasien $(53,65 \%$ 
dibandingkan dengan kelompok pola makan buruk sebanyak 14 pasien $(34,15 \%)$ dan kelompok pola makan baik sebanyak 5 pasien $(12,20 \%)$.

Menentukan pola makan ini diketahui dengan pemberian angket pada pasien yang terdiri dari pertanyaan menggunakan skala Guttman mengenai jenis makanan, frekuensi makanan dan keteraturan makan. Jenis makanan sangat berperan dalam pengosongan lambung. Pola makan yang dianjurkan adalah pola yang sumbangan energinya $60-70 \%$ berasal dari karbohidrat, 15-20\% dari protein dan 20-30\% dari lemak, disamping cukup akan vitamin, mineral dan serat. Pola makan tersebut terbagi dalam 3 periode yaitu sarapan, makan siang dan makan malam. Peranan sarapan tidak boleh diabaikan, karena makanan menentukan kerja tubuh dari pagi hingga siang hari. Jadi jadwal makan harus teratur, lebih baik makan dalam jumlah sedikit tapi sering dan teratur daripada makan dalam porsi banyak tapi tidak teratur (Almatsier, 2010). Perubahan pola makan meliputi tidak teraturnya waktu makan, frekuensi makan, jenis makanan dan porsi makanan yang dikonsumsi dapat mempengaruhi kekambuhan gastritis (Misnadiarly, 2009). Menurut Rahmi (2011), hasil penelitiannya menunjukkan bahwa ada hubungan yang signifikan antara pola makan dengan kejadian gastritis pada responden. Begitupun penelitian yang dilakukan oleh Megawati (2014) bahwa pola makan berpengaruh dengan kejadian gastritis, karena penderita gastritis dengan pola makan yang baik lebih banyak jika dibandingkan dengan penderita gastritis dengan pola makan kurang, sehingga pola makan akan berpengaruh terhadap tinggi rendahnya angka kejadian gastritis. Selain itu penelitian yang telah dilakukan oleh Yunita (2010) menyimpulkan bahwa terdapat hubungan terjadinya penyebab gastristis. Karena dimana merokok dapat menyebabkan lambatnya pengosongan lambung. Penelitian ini sejalan dengan Angkow (2014), dimana hasil penelitiannya diperoleh hubungan yang bermakna antara merokok dengan kejadian gastritis. Namun, tidak sesuai dengan penelitian yang dilakukan Rahmi (2011), yang menunjukkan bahwa tidak ada hubungan yang signifikan antara merokok dengan kejadian gastritis pada responden. Hal ini kemungkinan disebabkan oleh faktor-faktor lain yang lebih berpengaruh seperti kebiasaan makan dan stres. Selain itu, jumlah responden perempuan lebih banyak dibandingkan jumlah responden lakilaki dan prevalensi merokok pada laki-laki lebih tinggi daripada perempuan.

\section{e. Berdasarkan Pola Makan}

Tabel 5.Distribusi berdasarkan pola makan pasien gastritis di Puskesmas Wonorejo Samarinda Periode Agustus 2016 - September 2016

\begin{tabular}{lcc}
\hline \multicolumn{1}{c}{ Pola } & \multicolumn{2}{c}{ Jumlah } \\
makan & Frekuensi & Persentase (\%) \\
\hline Baik & 5 & 12,20 \\
Cukup & 22 & 53,65 \\
Buruk & 14 & 34,15 \\
\hline Total & $\mathbf{4 1}$ & $\mathbf{1 0 0}$ \\
\hline
\end{tabular}

Berdasarkan hasil penelitian yang telah diakukan, diketahui bahwa pasien antara tipe kepribadian, tempat tinggal, keteraturan dan frekuensi makan, konsumsi makan pedas, konsumsi makan asam dan frekuensi minuman iritatif dengan kejadian gastritis. Berdasarkan hasil penelitian yang dilakukan oleh Rahma (2013), bahwa makan tidak teratur berisiko 1,85 kali menderita gastritis dibandingkan dengan yang makan teratur, sehingga keteraturan makan merupakan faktor risiko kejadian gastritis. Sering mengonsumsi jenis makanan berisiko akan berisiko 2,42 kali menderita gastritis dibandingkan dengan yang 
tidak sering mengonsumsi jenis makanan yang berisiko dan frekuensi makan yang tidak tepat akan berisiko 2,33 menderita gastritis dibandingkan dengan frekuensi makan yang tepat.

\section{f. Berdasarkan Kebiasaan Merokok}

Tabel 6.Distribusi berdasarkan kebiasaan merokok pasien gastritis di Puskesmas Wonorejo Samarinda Periode Agustus 2016 - September 2016

\begin{tabular}{|c|c|c|}
\hline \multirow{2}{*}{$\begin{array}{c}\text { Kebiasaan } \\
\text { merokok }\end{array}$} & \multicolumn{2}{|c|}{ Jumlah } \\
\hline & Frekuensi & Persentase (\%) \\
\hline Merokok & 7 & 50 \\
\hline Tidak & 7 & 50 \\
\hline Total & 14 & 100 \\
\hline
\end{tabular}

Berdasarkan hasil penelitian diketahui bahwa pasien gastritis di Puskesmas Wonorejo Samarinda Periode Agustus 2016 - September 20162016 sama banyak terjadi pada kelompok tidak merokok dan merokok yaitu sebanyak 7 pasien $(50 \%)$ dengan semua responden laki-laki.

Hal ini dikarenakan responden lebih banyak terdapat pada kelompok perempuan dibandingkan dengan laki-laki. Karena perokok identik dengan laki-laki, walaupun sebenarnya juga ada perokok perempuan. Tetapi pada hasil penelitian yang telah di lakukan ini tidak ditemukan responden perempuan yang merokok. Dari 14 pasien laki-laki, hanya diperoleh 7 pasien yang merokok. Walaupun demikian, di mungkinkan merokok dapat mempengaruhi peradangan, bahkan hingga menyediakan stok obat NSAID dirumah jika sewaktu-waktu mengalami sakit. Jika pemakaiannya sekali kemungkinan terjadinya masalah lambung akan kecil. Tapi jika pemakaiannya dilakukan secara terus menerus atau pemakaiannya berlebihan dapat mengakibatkan gastritis dan peptic ulcer (Yulikustan, 2013). Penelitian ini sesuai dengan penelitian yang dilakukan oleh Megawati (2014) bahwa ada pengaruh mengkonsumsi obat-obatan yang berjenis NSAID dengan kejadian gastritis. Dimana responden yang mengkonsumsi obat-obatan, lebih banyak menderita gastritis dibandingkan dengan responden yang tidak menderita gastritis. Begitu pun hasil penelitian yang dilakukan oleh Rahma (2013), bahwa pernah menggunakan obat anti inflamasi non steroid berisiko 2,72 kali menderita gastritis dibandingkan dengan yang tidak pernah menggunakan obat anti inflamasi non steroid.

\section{g. Berdasarkan Konsumsi Obat NSAID}

Tabel 7.Distribusi berdasarkan konsumsi obat NSAID pasien gastritis di Puskesmas Wonorejo Samarinda Periode Agustus 2016 - September 2016

\begin{tabular}{lcc}
\hline \multicolumn{1}{c}{ Konsumsi } & \multicolumn{2}{c}{ Jumlah } \\
obat NSAID & Frekuensi & Persentase (\%) \\
\hline Mengonsumsi & 22 & 53,66 \\
Tidak & 19 & 46,34 \\
\hline Total & $\mathbf{4 1}$ & $\mathbf{1 0 0}$ \\
\hline
\end{tabular}


Berdasarkan hasil penelitian diketahui bahwa pasien gastritis di Puskesmas Wonorejo Samarinda Periode Agustus 2016 - September 20162016 lebih banyak terdapat pada kelompok yang mengonsumsi obat NSAID yaitu sebanyak 22 pasien $(53,66 \%)$ dibandingkan dengan kelompok yang tidak mengonsumsi obat NSAID sebanyak 19 pasien (46,34\%).

Dikatakan mengonsumsi obat NSAID adalah bagi responden yang langsung membeli dan minum obat karena keinginan sendiri atau rekomendasi dari keluarga, kerabat, tetangga atau masyarakat umum tanpa resep dari dokter atau konsultasi kepada tenaga kesehatan yang berwenang. Sehingga Obat NSAID dengan mudahnya dibeli jika merasa sakit mengalami keluhan seperti pusing, demam, nyeri, dan

Berdasarkan hasil penelitian pada Tabel 8, diketahui bahwa terapi obat yang diberikan pada pasien gastritis adalah antasida sebesar 21,95\% dengan jumlah 9 pasien, ranitidin sebesar 53,67\% dengan jumlah 22 pasien, famotidin dan omeprazol sebesar $12,19 \%$ dengan jumlah 5 pasien. Berdasarkan hasil tersebut dapat diketahui bahwa obat gastritis yang diberikan adalah golongan antasida, $\mathrm{H}_{2}$ Reseptor Antagonis $\left(\mathrm{H}_{2} \mathrm{RA}\right)$ dan Pompa Proton Inhibitor (PPI). Berdasarkan panduan praktik klinis bagi dokter pelayanan primer tahun 2014 yang dikeluarkan oleh Depkes RI dan Ikatan Dokter Indonesia (2014) hal 100, terapi yang diberikan antara lain $\mathrm{H}_{2} \mathrm{RA}$ (Ranitidin, Famotidin, Simetidin), PPI (Omeprazol, Lansoprazol) dan Antasida. Antasida digunakan untuk menetralkan asam lambung berlaku sebagai buffer terhadap hydrochloric acid lambung yang pada keadaan normal mempunyai $\mathrm{pH} 1-2, \mathrm{H}_{2} \mathrm{RA}$ digunakan untuk menghambat sekresi asam lambung di sel parietal dan PPI digunakan untuk menghambat atau memblokir kerja enzim $\mathrm{K}^{+} \mathrm{H}^{+}$ATPase (Pompa Proton) mencegah pengeluaran asam lambung dari sel kanalikuli.

\section{Pengobatan Pasien}

Tabel 8.Distribusi berdasarkan terapi obat pasien gastritis di Puskesmas Wonorejo Samarinda Periode Agustus 2016 - September 2016

\begin{tabular}{lcc}
\hline \multicolumn{1}{c}{ Terapi } \\
$\begin{array}{c}\text { Obat } \\
\text { Gastritis }\end{array}$ & Frekuensi & Jumlah \\
\hline Antasid & 9 & 21,95 \\
Ranitidin & 22 & 53,67 \\
Famotidin & 5 & 12,19 \\
Omeprazol & 5 & 12,19 \\
\hline Total & $\mathbf{4 1}$ & $\mathbf{1 0 0}$ \\
\hline
\end{tabular}

Tabel 9.Distribusi berdasarkan golongan obat pasien gastritis di Puskesmas Wonorejo Samarinda Periode Agustus 2016 - September 2016

\begin{tabular}{lcc}
\hline \multicolumn{1}{c}{ Gol. Obat } & \multicolumn{2}{c}{ Jumlah } \\
Gastritis & Frekuensi & Persentase (\%) \\
\hline Antasida & 9 & 21,95 \\
H2RA & 27 & 65,86 \\
PPI & 5 & 12,19 \\
\hline Total & $\mathbf{4 1}$ & $\mathbf{1 0 0}$ \\
\hline
\end{tabular}




\section{KESIMPULAN}

Berdasarkan hasil penelitian tentang karakteristik dan pengobatan pasien gastritis di Puskesmas Wonorejo Samarinda, maka dapat disimpukan sebagai berikut :

1. Karakteristik pasien didominasi oleh perempuan $65,85 \%$, masa usia dewasa akhir (36-45 tahun) 36,60\%, pendidikan terakhir SMA 58,54\%, pekerjaan sebagai Swasta 31,70\%, pola makan cukup 53,65\%, merokok 50\% dan mengonsumsi obat NSAID 53,66\%.

2. Pengobatan gastritis yang diberikan yaitu Ranitidin 53,67\%, Antasida 21,95\%, Famotidin dan Omeprazol 12,19\%.

\section{SARAN}

Saran untuk penelitian ini diharapkan agar dilakukan penelitian lebih lanjut terhadap kejadian DRPs dan edukasi terhadap pasien gastritis dengan metode pemberian leaflet atau brosur.

\section{DAFTAR PUSTAKA}

Almatsier. S, 2010, Prinsip Dasar Ilmu Gizi, Gramedia Pustaka Utama, Jakarta.

Angkow. J. dkk, 2014, Faktor-faktor yang Berhubungan dengan Kejadian Gastritis Wilayah Kerja Puskesmas Bahu Kota Manado, Program Studi Ilmu Keperawatan Fakultas Kedokteran Universitas Ram Satulangi Manado, Manado.

Choiro. Miftachul., Kusdariyah., dkk, 2014, The Relationship Between Stres Level and Gastritis Symptoms Case of grade IV Students in Thesis Progress of Hang Tuah Health Academy Surabaya. Jurnal STIKES Hang Tuah Surabaya, Surabaya.

Departemen Kesehatan RI dan IDI, 2014, Panduan Praktik Klinis Bagi Dokter di Fasilitas Pelayanan Kesehatan Primer Edisi II, Departemen Kesehatan Republik Indonesia, Jakarta.

Hanik. Murjayanah, 2010, Faktor - Faktor Risiko Yang Berhubungan Dengan Kejadian Gastritis Studi di RSU dr. R. Soetrasno Rembang, Skripsi,Semarang Fakultas Ilmu Keolahragaan Jurusan Ilmu Kesehatan Masyarakat.UNNESA,

Semarang.

Maulidiyah, 2006, Hubungan Antara Stres dan Kebiasaan Makan dengan Terjadinya Kekambuhan Penyakit gastritis, Jurnal Universitas Airlangga Volume 7 Nomor 3.

Megawati., Andi, 2014, Beberapa Faktor yang Berhubungan dengan Kejadian gastritis pada Pasien yang dirawat di RSUD Labuang Baji Makassar, Volume 4 Nomor 1 Tahun 2014, ISSN : 2302-1721.

Misnadiarly, 2009, Mengenal Penyakit Organ Cerna : Gastritis, Pustaka Populer OBDA, Jakarta.

Nasution. K., dan Adi. NP, 2011, Stres Okupasi, Masalah Kesehatan Pekerja yang Terabaikan, Journal Indonesian Association Vol 61 No.12.

Prasetyo. Danang, 2015, Hubungan Antara Stres Dengan Kejadian Gastritis di Klinik Dhanang Husada Sukoharjo, Skripsi Program Studi Keperawatan Stikes Kusuma Husada Surakarta, Surakarta. 
Rahma. Mawaddah., dkk., 2013, Faktor Resiko Kejadian Gastritis di Wilayah Kerja Puskesmas Kampili Kabupaten Gowa Makassar, Jurnal Media Kesehatan masyarakat Indonesia Universitas Hasanuddin Makassar, Makassar.

Rahmi. Gustin, 2011, Faktor-faktor yang berhubungan dengan Kejadian Gastritis pada Pasien yang Berobat Jalan di Puskesmas Gulai Bancah Kota Bukit Tinggi Tahun 2011, Artikel Penelitian Universitas Andalas

Sunaryo, 2004, Psikologi Untuk Keperawatan, Penerbit EGC, Jakarta.

Zilmawati. R., 2007, Faktor-Faktor yang Berhubungan dengan Gejala Gastritis pada Mahasiswa Tingkat IV Fakultas Kesehatan Masyarakat Universitas Baiturrahmah Padang Tahun 2007, Skripsi Fakultas Kesehatan Masyarakat Universitas Baiturrahmah, Padang. 